\title{
New extinct ant genus (Hymenoptera, Formicidae, Myrmicinae) from late Eocene Rovno amber
}

\author{
Alexander G. Radchenko', Maxim Yu. Proshchalykin ${ }^{2}$ \\ I I. I. Schmalhausen Institute of zoology of National Academy of Sciences of Ukraine, Kiev, 01030, Ukraine \\ 2 Federal Scientific Center of the East Asia Terrestrial Biodiversity, Far East Branch of the Russian Academy of \\ Sciences, Vladivostok 690022, Russia \\ Corresponding author: Alexander G. Radchenko (agradchenko@hotmail.com) \\ Academic editor: V. Gokhman | Received 28 February 2021 | Accepted 10 April 2021 | Published 24 August 2021 \\ http://zoobank.org/0789CE62-57A5-4E5E-B2EE-31B936A673DC \\ Citation: Radchenko AG, Proshchalykin MYu (2021) New extinct ant genus (Hymenoptera, Formicidae, Myrmicinae) \\ from late Eocene Rovno amber. In: Proshchalykin MYu, Gokhman VE (Eds) Hymenoptera studies through space and \\ time: A collection of papers dedicated to the $75^{\text {th }}$ anniversary of Arkady S. Lelej. Journal of Hymenoptera Research 84: \\ 271-282. https://doi.org/10.3897/jhr.84.65238
}

\begin{abstract}
A new fossil myrmicine ant genus and species Lelejus venustus gen. et sp. nov., are described from late Eocene Rovno amber (Priabonian, 33.9-37.8 Ma). This genus differs from all extant and extinct Myrmicinae genera known from the late Eocene European ambers in the combination of morphological features, in particular: 13-segmented antennae with a very short scape and filiform funiculus; 3-segmented maxillary and 2-segmented labial palps; well-developed mandibles with dentate masticatory margin; scutum with broad notauli; forewings with closed cells $1+2 \mathrm{r}, 3 \mathrm{r}$ and $\mathrm{mcu}$, the cell $3 \mathrm{r}$ of approximately the same length as cell $1+2 \mathrm{r}$; free vein $\mathrm{M}$ branches off from RS approximately at the midlength between the junction of cross-vein $2 \mathrm{r}$-rs with RS and vein $\mathrm{m}$-cu; the cross-vein cu-a is located far from the base of wing, so the branch $1 \mathrm{M}+\mathrm{Cu}$ is much longer than $2 \mathrm{M}+\mathrm{Cu}$. The taxonomic position of the described genus is discussed.
\end{abstract}

\section{Keywords}

Lelejus venustus gen. et sp. nov., fossils, paleontology, taxonomy 


\section{Introduction}

The diversity of the fossil ant fauna is very rich: more than 800 extinct species, 164 genera and six subfamilies are known now (Bolton 2021; our unpublished data). However, five fossil subfamilies with 20 genera and 45 species became extinct at the end of the Cretaceous. One mysterious subfamily, Formiciinae Lutz, 1986, contained giant ants with a body length of gynes up to $7 \mathrm{~cm}$ and wingspan up to $15 \mathrm{~cm}$, known from deposits of the early and middle Eocene of Europe and North America. Thus, all the late Eocene ants already belonged to modern subfamilies.

In general, the ant fauna of the late Eocene (Priabonian, 33.9-37.8 Ma) European (Baltic, Bitterfeld, Scandinavian and Rovno) ambers is probably the best studied among all fossil myrmecofaunas in the world. It includes more than 17,500 specimens belonging to more than 200 extinct species from 34 extinct and 39 modern genera of 12 existing subfamilies (Dlussky and Rasnitsyn 2009; Dlussky et al. 2014; Perkovsky 2016, 2018; our unpublished data).

At present, Myrmicinae is the most diverse ant subfamily, which includes 147 genera with almost 7,000 species. This group therefore represents about $45 \%$ ant genera and more than $50 \%$ species (calculated from the data from Bolton 2021), but the ratio of subfamilies in the past was different.

The most comprehensive monographic revision of the ants of Baltic amber was published over than 100 years ago (Wheeler 1915), where twelve Myrmicinae genera (28\%) and 24 species (27\% known amber ants; based on the modern taxonomy) were reported. Interestingly, from 1915 until the beginning of the present century neither new genera nor new species of Myrmicinae were discovered. Two new myrmicine species were described only in 2002 (Dlussky and Perkovsky 2002), soon followed by description of seven new genera and 31 species (Dlussky and Radchenko 2006a, b, 2009; Radchenko and Perkovsky 2009; Radchenko and Dlussky 2012, 2013a, b, 2015, 2016, 2017a, b, 2018a, b, c, 2019; Radchenko et al. 2007, 2018, 2019; Radchenko 2020). Another new genus and species were recently described by Cheny et al. (2019). Thus, together with a new genus established below, the number of Myrmicinae genera in late European ambers reaches 25 (with 13 of them extinct), and if undescribed taxa are included, 85 species, or 34\% and 39\% amber ant genera and species, respectively.

\section{Material and methods}

A new genus and a new species, Lelejus venustus gen. et sp. nov., are established on the base of a single male in a piece of Rovno amber. The holotype specimen is deposited in the collection of the I.I. Schmalhausen Institute of Zoology of NAS of Ukraine, Kiev (SIZK).

The photographs were taken with a Leica Z16 APO stereomicroscope equipped with Leica DFC 450 camera and processed with LAS Core software. 
Not all features of the examined specimen were properly visible and measurable, hence we measured only well-discernible details (with $0.01 \mathrm{~mm}$ resolution), in particular:

HL maximum length of the head in dorsal view, measured in a straight line from the anteriormost point of clypeus to the mid-point of occipital margin;

HW maximum width of the head in dorsal view just behind (above) the eyes;

FW minimum width between the frontal carinae;

SL maximum length of the scape measured in a straight line from its apex to the articulation with condylar bulb;

OL maximum diameter of the eye;

GL length of the genae, measured from the anterior margin of the eyes to the articulation with the mandible;

MdL length of the mandible from the tip of apical tooth to the outer point of insertion with the head;

ML diagonal length of the mesosoma seen in profile from the anterior-upper margin of pronotum to the posterior margin of propodeal lobes;

MH height of the mesosoma, measured from the upper level of scutum perpendicularly to the level of lower margin of mesopleuron;

PL maximum length of the petiole, measured from the posterodorsal margin of the petiole to the articulation with the propodeum;

PH maximum height of the petiole in profile, measured from the uppermost point of the petiolar node perpendicularly to the lowest point of the petiole;

PPL maximum length of the postpetiole in profile;

PPH maximum height of the postpetiole in profile;

HTL maximum length of the metatibia;

WL maximum length of the forewing;

WW maximum width of the forewing.

The approximate total length is calculated as the sum of $\mathrm{HL}+\mathrm{ML}+\mathrm{PL}+$ length of the gaster.

\section{Indices:}

$\mathrm{CI}=\mathrm{HL} / \mathrm{HW}, \mathrm{FI}=\mathrm{FW} / \mathrm{HW}, \mathrm{SI} 1=\mathrm{SL} / \mathrm{HL}, \mathrm{SI} 2=\mathrm{SL} / \mathrm{HW}, \mathrm{MdI}=\mathrm{MdL} / \mathrm{HL}, \mathrm{OI} 1=\mathrm{OL} / \mathrm{HL}$, $\mathrm{OI}=\mathrm{OL} / \mathrm{HW}, \mathrm{PI} 1=\mathrm{PL} / \mathrm{HL}, \mathrm{PI}=\mathrm{PL} / \mathrm{PH}, \mathrm{MI}=\mathrm{ML} / \mathrm{MH}, \mathrm{WI}=\mathrm{WL} / \mathrm{WH}$.

Nomenclature of the wing venation is given according to Dlussky (2009) and Dlussky and Perfilieva (2014) (see also Fig. 4).

\section{Indices of forewing venation:}

$\mathrm{Icu}=[1 \mathrm{Cu}+(2 \mathrm{M}+\mathrm{Cu})] / 1 \mathrm{Cu}$

Icua $=[(1 \mathrm{M}+\mathrm{Cu})+(2 \mathrm{M}+\mathrm{Cu})] /(1 \mathrm{M}+\mathrm{Cu})$ 


\section{Taxonomy}

\section{Order Hymenoptera Linnaeus, 1758}

Family Formicidae Latreille, 1809

Subfamily Myrmicinae Lepeletier de Saint-Fargeau, 1835

\section{Genus Lelejus gen. nov. \\ http://zoobank.org/BA1BE4FC-8712-4E90-81AD-DCE8F8A021BE}

\section{Type species. Lelejus venustus sp. nov.}

Diagnosis. Antennae 13-segmented, inserted into head very close to posterior clypeal margin; scape very short, less than total length of first and second funicular segments, funiculus filiform, without apical club. Palp formula 3, 2. Mandibles well developed, subtriangular, masticatory margin with larger basal tooth, four minor sharp teeth and much longer sharp apical tooth. Median portion of clypeus evenly convex, without median and lateral carinae, its anterior margin convex, without a notch. Scutum with broad notauli. Propodeum distinctly angulated in profile, its dorsal surface delineated laterally by sharp longitudinal ridges. All meso- and metatibiae with welldeveloped simple spur, pretarsal claws simple. Forewing with closed cells $1+2 \mathrm{r}, 3 \mathrm{r}$ and mcu; cell $3 r$ relatively short, about the same length as cell $1+2 r$; free vein $M$ branching off from RS approximately at the midlength between junction of cross-vein $2 \mathrm{r}$-rs with RS and vein $\mathrm{m}$-cu; cross-vein cu-a located far from base of wing, so that branch $1 \mathrm{M}+\mathrm{Cu}$ much longer than $2 \mathrm{M}+\mathrm{Cu}, \mathrm{Icu}=1.75$, Icua $=1.28$. Hind wing without jugal lobe; free abscissa $\mathrm{M}$ absent; branch $1 \mathrm{RS}$ well developed; vein cu-a located close to base of wing, so that branch $1 \mathrm{M}+\mathrm{Cu}$ much shorter than $2 \mathrm{M}+\mathrm{Cu}$, Icua $=2.37$.

Etymology. The new genus is named in honor of our colleague and friend Prof. Arkady S. Lelej (Federal Scientific Center of the East Asia Terrestrial Biodiversity, Vladivostok, Russia) on the occasion of his $75^{\text {th }}$ birthday and in recognition of his great contributions to the study of Hymenoptera.

Comparative diagnosis. The described genus differs from any extant and extinct myrmicine genera known from the late Eocene European ambers by unique combination of the above mentioned features (for details see Discussion). Among these characters, the broad, foveate notauli and mandibles with six teeth are particularly distinctive of the new genus.

\section{Lelejus venustus sp. nov.}

http://zoobank.org/C9378CD0-53D8-447C-8357-A595CDAEEF91

Figures $1-4$

Material examined. Holotype: male, SIZK No. UA-27845, Ukraine, Rovno Region, Klesov, Rovno amber, late Eocene, 33.9-37.8 Ma; AntWebCASENT0917546.

Diagnosis. As for the genus. 

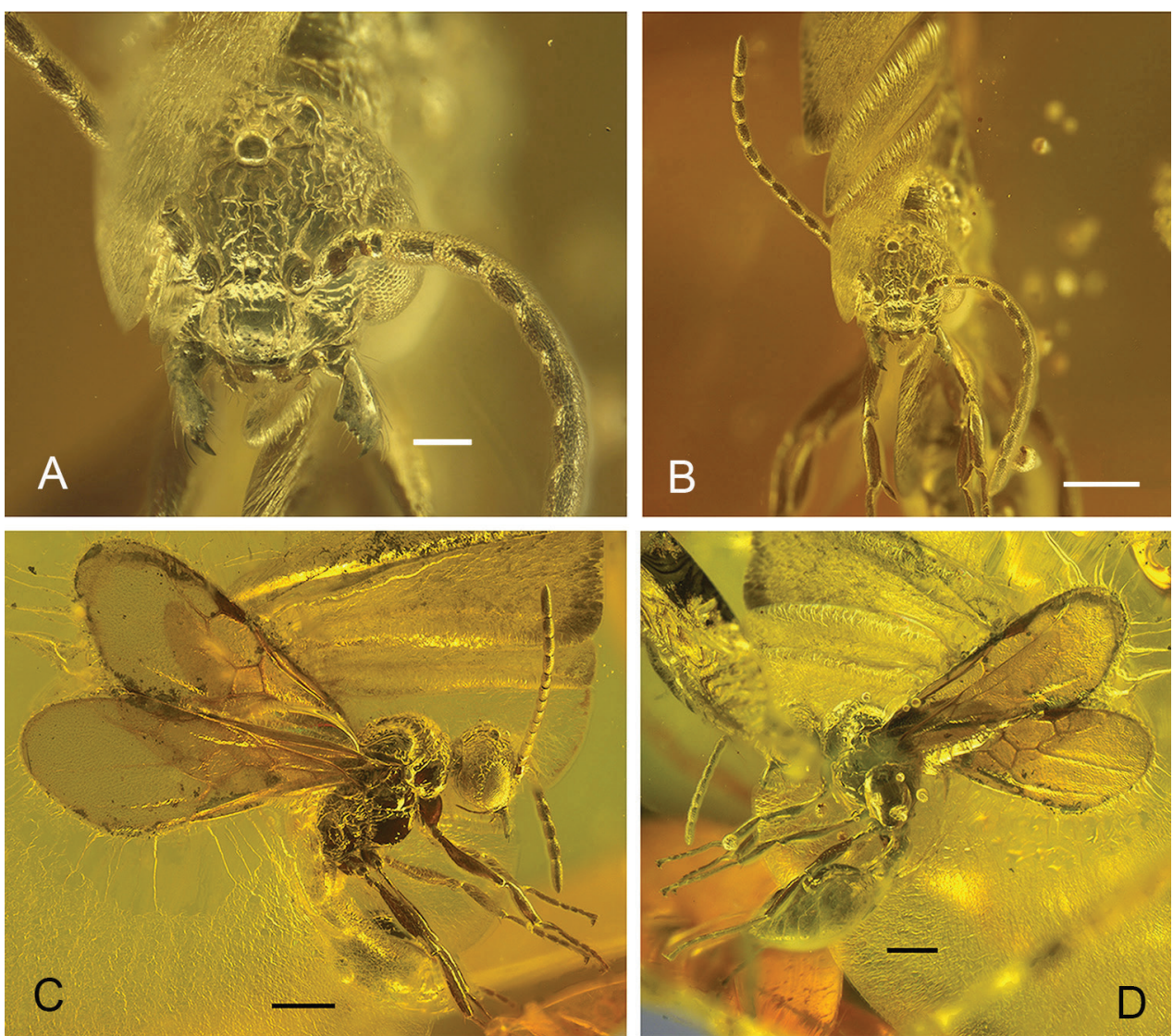

Figure I. Lelejus venustus gen. et sp. nov., holotype, male (AntWebCASENT0917546) A head, dorsal view $\mathbf{B}$ head and antennae, dorsal view C, D body, right lateral view (C); left dorso-lateral view (D). Scale bars: $0.1 \mathrm{~mm}(\mathbf{A}) ; 0.5 \mathrm{~mm}(\mathbf{B}-\mathbf{D})$.

Description. Male. Body length $4.1 \mathrm{~mm}$. Head subglobular, slightly wider than long, gradually rounded behind eyes, without marked occipital corners and with convex occipital margin. Eyes very large, their maximum diameter half of head length, situated distinctly in front of mid-length of sides of head, so genae very short. Ocelli large, forming obtuse triangle, diameter of central ocellus subequal to width of scape. Frons relatively narrow, 0.25 head width, frontal sockets fully exposed. Frontal triangle well marked. Mandibles quite long, ca. 0.4 head length. Apical segment of maxillary palps twice as long as preapical one. Antennal scape ca. twice as long as width and ca. 4.5 times shorter than head. First funicular segment very short, somewhat shorter than wide and half as long as second segment; all subsequent segments of same width; second to $11^{\text {th }}$ segment subequal in length, last segment twice as long as second one. Whole head with coarse reticulation, clypeus with sinuous longitudinal rugae, its central part and mandibles smooth; eyes surrounded by narrow foveate groove. Temples and occipital margin with quite numerous subdecumbent hairs of moderate length; 


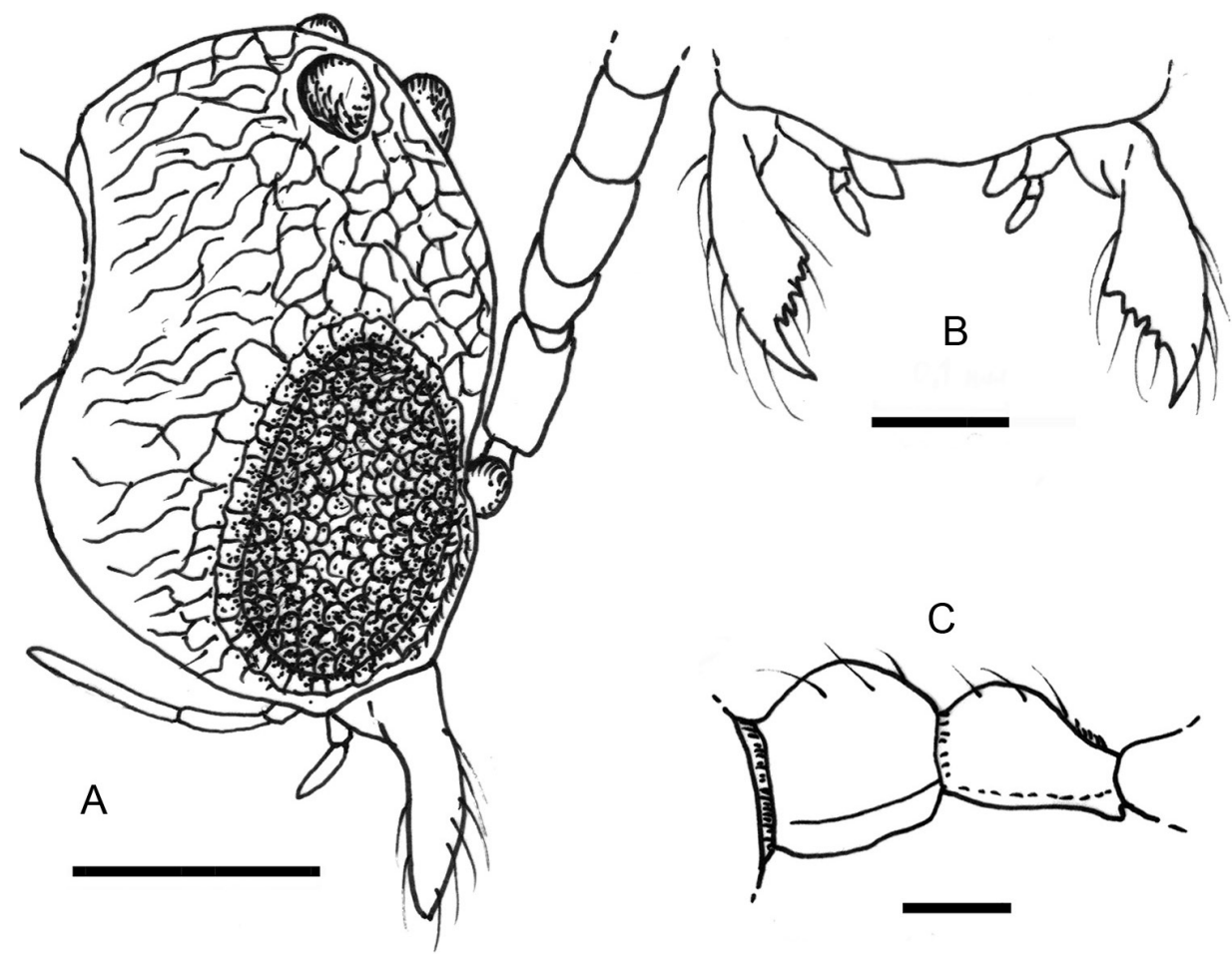

Figure 2. Lelejus venustus gen. et sp. nov., holotype, male $\mathbf{A}$ head, lateral view $\mathbf{B}$ mandibles $\mathbf{C}$ petiole and postpetiole, lateral view. Scale bars: $0.25 \mathrm{~mm}(\mathbf{A}) ; 0.1 \mathrm{~mm}(\mathbf{B}, \mathbf{C})$.

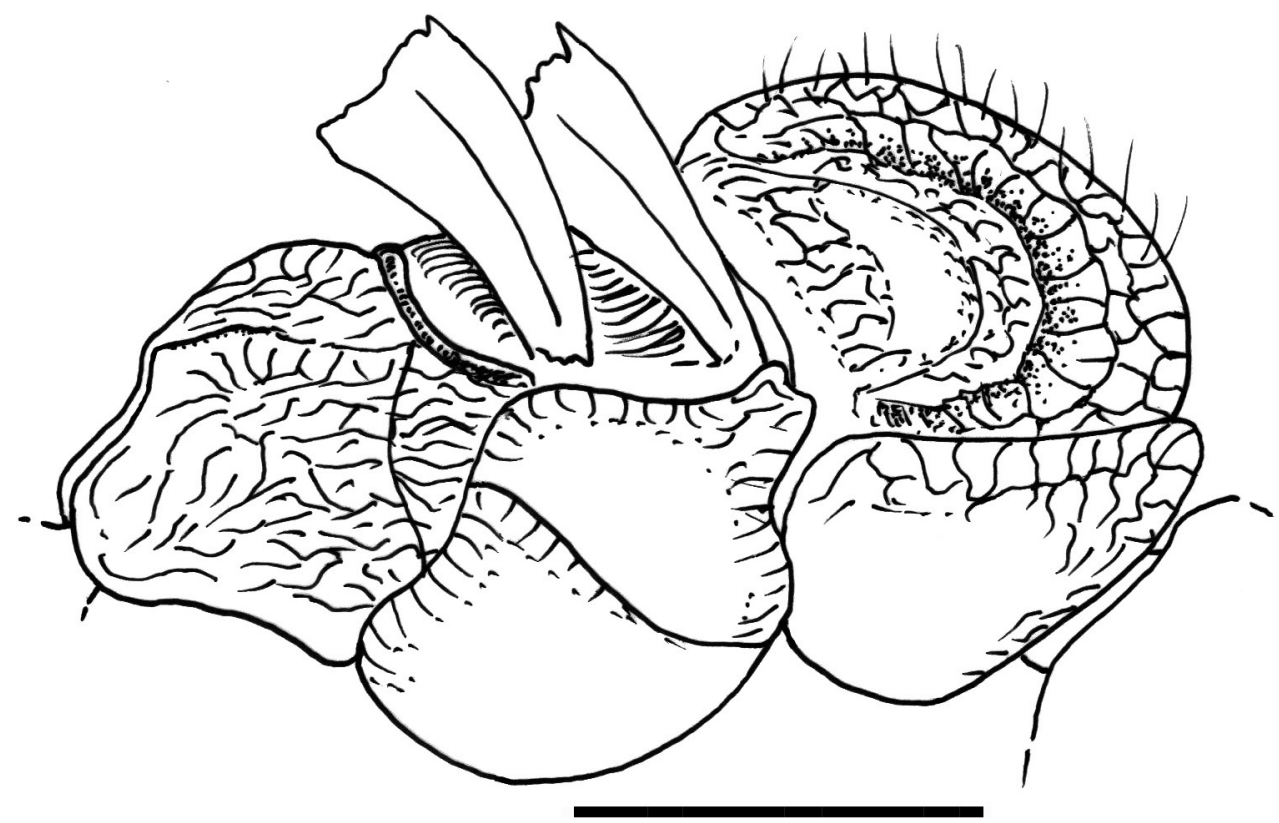

Figure 3. Lelejus venustus gen. et sp. nov., holotype, male, mesosoma, lateral view. Scale bar: $0.5 \mathrm{~mm}$. 

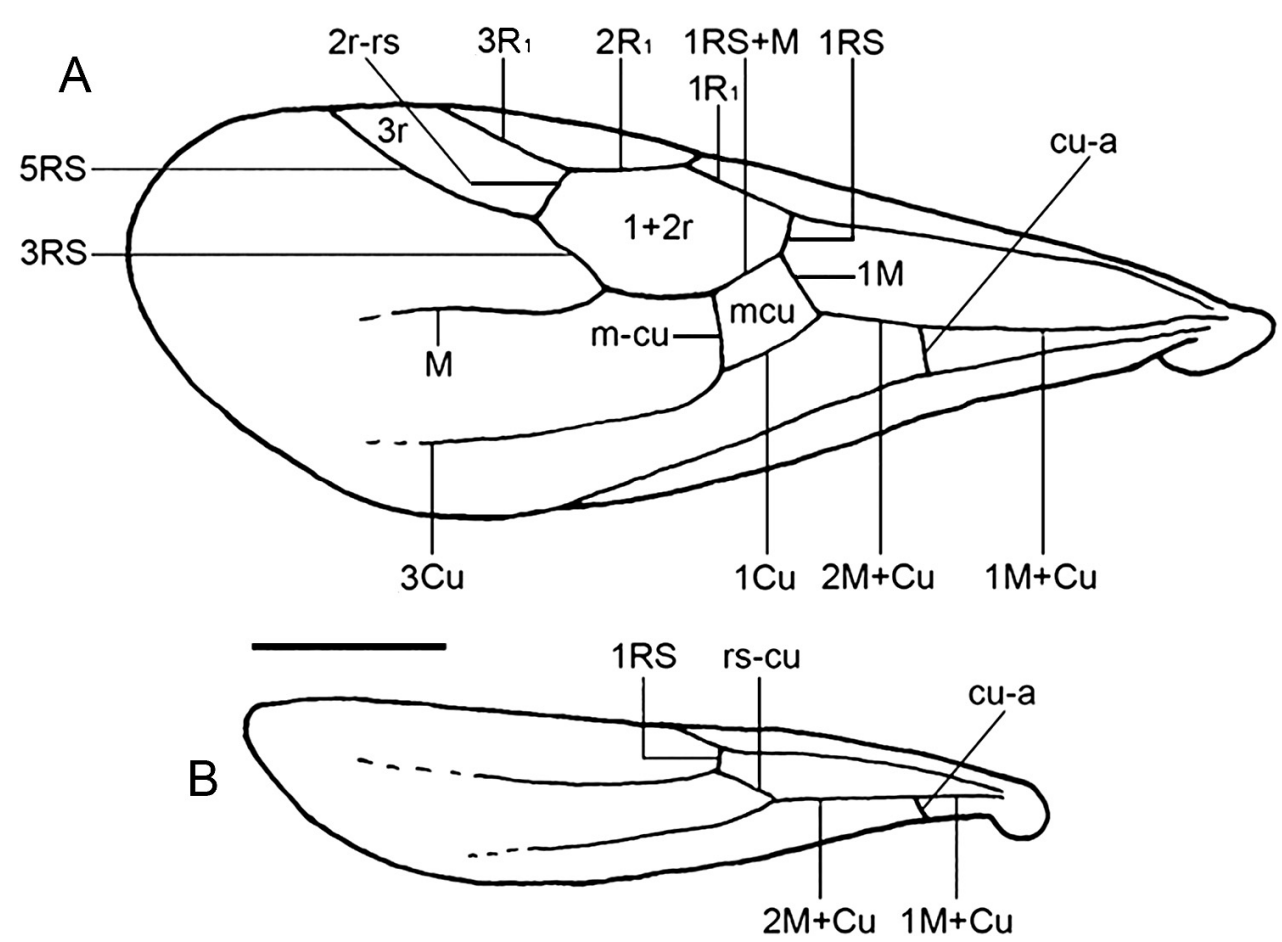

Figure 4. Lelejus venustus gen. et sp. nov., holotype, male $\mathbf{A}$ forewing $\mathbf{B}$ hind wing. Scale bar: $0.5 \mathrm{~mm}$.

antennal scape with sparse subdecumbent, but quite long hairs; funicular segments with very short and abundant decumbent to subdecumbent pilosity; anterior clypeal margin without long setae, with only a few short, thin hairs; mandibles with quite long semierect hairs.

Mesosoma 1.6 times as long as high, scutum moderately convex, posterior surface of propodeum 1.2 times as long as dorsal one. Notauli deep and wide, distinctively arched in profile view, with coarse short transverse rugae (foveate). Petiole with distinct peduncle, 1.6 times as long as high, its node with widely rounded dorsum; postpetiole subglobular, slightly higher than petiole. Spurs on meso- and metatibiae relatively long, equal to width of tibia at point of their articulation. Scutum, scutellum and propodeal dorsum with coarse reticulation; sides of pronotum, mesopleura and lower part of sides of propodeum smooth; gaster smooth.

Mesosoma, waist and gaster with moderately dense erect to semierect hairs, legs with decumbent to subdecumbent pilosity, femora with additional longer suberect hairs. Genitalia small and barely visible. Forewings: pterostigma rather long and narrow; cross-vein rs-m completely reduced, so that cell rm absent; cell mcu of moderate size, trapezoidal, its height subequal to midline, its distal point does not reach level of basal end of pterostigma, vein section $1 \mathrm{RS}+\mathrm{M}$ somewhat shorter than $1 \mathrm{Cu}$; cell $1+2 \mathrm{r}$ heptagonal, relatively short, veins $1 \mathrm{R}_{1}, 2 \mathrm{R}_{1}$ and $3 \mathrm{R}_{1}$ of nearly equal length; vein sections $2 \mathrm{RS}+\mathrm{M}$ and $3 \mathrm{RS}$ subequal in length; cross-veins $2 \mathrm{r}-\mathrm{rs}$ and $1 \mathrm{RS}$ well developed, 
$1 \mathrm{RS}$ slightly inclined toward base of wing, $2 \mathrm{r}$-rs almost perpendicular to $2 \mathrm{R}_{1}$ and $3 \mathrm{R}_{1}$ at the point of their junction.

Measurements (in mm). HL 0.73, HW 0.77, FW 0.19, SL 0.16, OL 0.36, GL 0.06, MdL 0.30, ML 1.43, MH 0.88, PL 0.39, PH 0.27, PPL 0.27, PPH 0.29, HTL 0.60 , WL 3.18, WW 1.13; length of funicular segments from second to $11^{\text {th: }}: 0.13$, $0.13,0.14,0.14,0.14,0.14,0.14,0.14,0.16,0.26$.

Indices: CI 0.95, SI1 0.22, SI2 0.21, FI 0.25, MdI 0.41, OI1 0.50, OI2 0.47, PI1 0.54, PI2 1.58, PPI1 0.39, PPI2 0.95, MI 1.62, WI 2.83.

Workers and queens. Unknown.

Etymology. From Latin venustus - pretty, nice, fine, which means that the described specimen has a fine general appearance.

\section{Discussion}

Males are known for 17 of 24 Myrmicinae genera (six of which are extinct), previously found in late Eocene European ambers. Lelejus gen. nov. can be easily distinguished from the extant Aphaenogaster Mayr, 1853, Carebara Westwood, 1840, Crematogaster Lund, 1831, Monomorium Mayr, 1855, Solenopsis Westwood, 1840 and Vollenhovia Mayr, 1865 by the presence of notauli (not to mention many other features). It also differs well from other modern genera that have notauli, particularly: in Myrmica Latreille, 1804 the palp formula is 6 , 4; forewings have closed cell $1+2 \mathrm{r}+\mathrm{rm}$, partially separated by a short vein, and cell $3 \mathrm{r}$ is always open; Pristomyrmex Mayr, 1866 has 12-segmented antennae, reduced mandibles and an open cell 3r on the forewings; Stenamma Westwood, 1839 has a much longer antennal scape (SI1 $\geq 0.40$ ), a noticeably longer head (CI $>1.20)$, and cell $3 \mathrm{r}$ on the forewing open; similarly to Stenamma, Temnothorax Mayr, 1861 also has a longer antennal scape (SI1 $\geq 0.30$ ), cell 3r on the forewing open, meso- and metatibiae have no spurs, and the palp formula is 5, 3; finally, Tetramorium Mayr, 1855 has 10-segmented antennae with a very long second funicular segment, which is markedly longer than the three subsequent segments together.

Similarly to Lelejus gen. nov., known males of all extinct Myrmicinae genera from late Eocene European ambers have notauli. However, these are never as broad and foveate as in Lelejus gen. nov., except for Proleptothorax Radchenko, Dlussky \& Perfilieva, 2018 (see below). Additionally, Lelejus gen. nov. well differs from any of these genera in a set of other features. Thus, the anterior clypeal margin in Bilobomyrma Radchenko \& Dlussky, 2013 is strongly notched medially and with two lateral lobes, the head is much longer $(\mathrm{CI}>1.20)$, and meso- and metatibiae without spur; Electromyrmex Wheeler, 1915 has a distinctly longer antennal scape $($ SI1 $>0.45)$ and funiculus with a distinct 4-segmented club, a very long petiole without a node (PI2 > 3.30), meso- and metatibiae without spur, and forewing with closed cells $1+2 \mathrm{r}$, rm and mcu, but cell $3 \mathrm{r}$ open; Eocenomyrma Dlussky \& Radchenko, 2006 has a much longer antennal scape (SI1 0.50), a rather long head (CI 1.18), relatively smaller eyes (OI1 0.35), mesoand metatibiae without spur, and cell $3 \mathrm{r}$ on the forewing open; both Plesiomyrmex 
Dlussky \& Radchenko, 2009 and Protomyrmica Dlussky \& Radchenko, 2009 have pectinate meso- and metatibial spurs and closed cells $1+2 \mathrm{r}$, rm and mcu on the forewing; Proleptothorax Radchenko, Dlussky \& Perfilieva, 2018 resembles Lelejus gen. nov. by the general pattern of forewing venation, antennal structure, shape of the head, presence of simple spurs on the middle and hind tibiae, but well differs by the short and narrow bidentate mandibles, longer head (CI 1.12), shorter and higher petiole (PI2 2.00), and by the 5-segmented maxillary and 3-segmented labial palps. Both these genera have wide foveate notauli, but they are Y-shaped in Proleptothorax and V-shaped in Lelejus gen. nov. (for a more detailed comparison see Dlussky and Radchenko 2009; Radchenko and Dlussky 2013a, 2016, 2018c; Radchenko et al. 2018).

Most of the morphological features of Lelejus gen. nov. can be considered as plesiomorphies in Myrmicinae. These are 13-segmented antennae with the short scape and filiform funiculus without an apical club; head without marked occipital corners and with convex occipital margin; subtriangular mandibles with a well-developed and dentate masticatory margin; unmodified clypeus; scutum with notauli; unmodified petiole and postpetiole; simple pretarsal claws; closed cell $3 \mathrm{r}$ on the forewing. On the other hand, the reduced number of segments of maxillary and labial palps $(3,2)$, presence of the simple spur (instead of pectinate) on the meso- and metatibiae, and reduced cell $\mathrm{rm}$ on the forewing are apomorphies. Nevertheless, based on the above, we cannot attribute Lelejus gen. nov. to any Myrmicinae tribe, and we cannot consider it as an ancestor of any known extinct or extant genera.

Of the 11 extant genera found in late Eocene European ambers, fossil males are known in six of them. These of Stenamma, Aphaenogaster and Carebara do not differ from extant species in the main diagnostic features (Wheeler 1915; Radchenko et al. 2019), but others possess a set of plesiomorphies compared to modern species. Thus, Crematogaster primitiva Radchenko \& Dlussky, 2019 has 13-segmented antennae in contrast to 11- or 12-segmented ones in modern species. The forewings of Pristomyrmex archaios Radchenko \& Dlussky, 2018 have closed cells $1+2 \mathrm{r}$ and mcu, while the cell mcu is completely reduced in extant species. Antennae in males of extinct Temnothorax species have an almost indistinct apical club instead of 4-segmented in modern species (Radchenko and Dlussky 2018b, 2019; Radchenko et al. 2018).

In general, the majority of the extinct amber genera of Myrmicinae are quite specialized and cannot be considered the ancestors of modern ants. Only two genera might be treated as the putative ancestors of extant genera: Parameranoplus Wheeler, 1915 of Meranoplus Smith, 1853, and Proleptothorax of the genera of the Leptothorax genus-group, but not of Temnothorax (Wheeler 1915; Radchenko et al. 2018).

\section{Acknowledgements}

We are sincerely grateful to Dr Ksenia Perfilieva (Moscow) for valuable help with the description of wing venation, to Dr Kateryna Martynova (Kiev) for taking images of the holotype specimen, as well as to the guest editor (Dr Vladimir 
Gokhman, Moscow) and two reviewers for their valuable comments, which helped to improve the quality of this paper. This work was supported by grants NRFU No. 2020/02/0369 (to A.G. Radchenko) and RFBR/MECSS No. 20-54-44014 (to M.Yu. Proshchalykin).

\section{References}

Bolton B (2021) An online catalog of the ants of the world. http://antcat.org [accessed 15 January 2021]

Chény C, Wang B, Perrichot V (2019) A new genus of myrmicine ant (Hymenoptera: Formicidae) from Eocene Baltic amber. Comptes Rendus Palevol 18(6): 589-597. https://doi. org/10.1016/j.crpv.2019.05.005

Dlussky GM (2009) The ant subfamilies Ponerinae, Cerapachyinae, and Pseudomyrmecinae (Hymenoptera, Formicidae) in the Late Eocene ambers of Europe. Paleontological Journal 43(9): 1043-1086. https://doi.org/10.1134/S0031030109090068

Dlussky GM, Perfilieva KS (2014) Superfamily Formicoidea Latreille, 1802. In: Antropov AV, Belokobylskij SA, Compton SG, Dlussky GM, Khalaim AI, Kolyada VA, Kozlov MA, Perfilieva KS, Rasnitsyn AP (Eds) The wasps, bees and ants from the Insect Limestone (Late Eocene) of the Isle of Wight, U.K. Earth and Environmental Science Transactions of the Royal Society of Edinburgh 104(3-4): 410-438. https://doi.org/10.1017/ S1755691014000103

Dlussky GM, Perkovsky EE (2002) Ants (Hymenoptera, Formicidae) from Rovno amber. Vestnik zoologii 35(5): 3-20. [in Russian] https://www.antwiki.org/wiki/images/e/e5/ Dlussky_\%26_Perkovsky_2002.pdf

Dlussky GM, Radchenko A (2006a) Fallomyrma gen. nov., a new myrmicine ant genus (Hymenoptera: Formicidae) from the Late Eocene European amber. Annales Zoologici 56(1): 153-157. https://www.antwiki.org/wiki/images/f/fd/Dlussky_\%26_Radchenko_2006.pdf

Dlussky GM, Radchenko A (2006b) New ant genus from the Late Eocene European Amber. Acta Palaeontologica Polonica 51(3): 561-567. https://www.antwiki.org/wiki/images/6/62/Dlussky_\%26_Radchenko_2006b.pdf

Dlussky G, Radchenko A (2009) Two new primitive ant genera from the European amber (late Eocene). Acta Palaeontologica Polonica 54(3): 435-441. https://doi.org/10.4202/ app.2008.0092

Dlussky G, Radchenko A, Dubovikoff D (2014) A new enigmatic ant genus from late Eocene Danish Amber and its evolutionary and zoogeographic significance. Acta Palaeontologica Polonica 59(4): 931-939. https://doi.org/10.4202/app.2012.0028

Dlussky GM, Rasnitsyn AP (2009) Ants (Insecta: Vespida: Formicidae) in the Upper Eocene amber of Central and Eastern Europe. Paleontological Journal 43(9): 1024-1042. https:// doi.org/10.1134/S0031030109090056

Perkovsky EE (2016) Tropical and Holarctic ants in Late Eocene ambers. Vestnik zoologii 50(2): 111-122. https://doi.org/10.1515/vzoo-2016-0014 
Perkovsky EE (2018) Only a half of species of Hymenoptera in Rovno amber is common with Baltic amber. Vestnik zoologii 52(5): 353-360. https://doi.org/10.2478/vzoo-2018-0037 Radchenko A (2020) New species of extinct ant genus Eocenomyrma Dlussky et Radchenko (Hymenoptera: Formicidae: Myrmicinae) from the Baltic amber. Annales Zoologici 70(1): 109-111. https://doi.org/10.3161/00034541ANZ2020.70.1.005

Radchenko AG, Dlussky GM (2012) Boltonidris gen. nov., the first extinct Stenammini ant genus from the Late Eocene Rovno amber. Annales Zoologici 62(4): 627-631. https://doi. org/10.3161/000345412X659687

Radchenko A, Dlussky GM (2013a) Bilobomyrma n. gen., a new extinct ant genus (Hymenoptera, Formicidae) from the late Eocene European ambers. Journal of Paleontology 87(6): 1060-1066. https://doi.org/10.1666/13-013

Radchenko A, Dlussky GM (2013b) Vollenhovia kipyatkovi sp. nov., a new fossil ant species (Hymenoptera, Formicidae, Myrmicinae) from the Rovno amber (late Eocene). Proceedings of the Russian Entomological Society 84(2): 92-97. https://doi.org/10.47640/16057678_2013_84_2_92

Radchenko AG, Dlussky GM (2015) First record of fossil species of the genus Tetramorium Mayr (Hymenoptera, Formicidae). Vestnik zoologii 49(4): 311-316. https://doi. org/10.1515/vzoo-2015-0033

Radchenko AG, Dlussky GM (2016) Further data on the extinct ant genus Eocenomyrma (Hymenoptera, Formicidae). Vestnik zoologii 50(5): 395-406. https://doi.org/10.1515/vzoo2016-0046

Radchenko AG, Dlussky GM (2017a) New species of the extinct ant genus Stigmomyrmex Mayr and designation of the neotype of Stiphromyrmex robustus (Mayr) (Hymenoptera, Formicidae, Myrmicinae). Annales Zoologici 67(4): 773-780. https://doi.org/10.3161/0 0034541ANZ2017.67.4.012

Radchenko A, Dlussky GM (2017b) Further records of the extinct ant genus Enneamerus Mayr (Hymenoptera, Formicidae) from the Late Eocene European ambers. Asian Myrmecology 9: 1-11. https://doi.org/10.20362/am.009012

Radchenko AG, Dlussky GM (2018a) Ants of the Genus Fallomyrma Dlussky et Radchenko (Hymenoptera, Formicidae, Myrmicinae) from Late Eocene European Ambers. Paleontological Journal 52(2): 155-163. https://doi.org/10.1134/S0031030118020107

Radchenko A, Dlussky GM (2018b) Two new fossil species of the ant genus Pristomyrmex Mayr (Hymenoptera, Formicidae) from the Rovno and Bitterfeld ambers. Annales Zoologici 68(2): 251-258. https://doi.org/10.3161/00034541ANZ2018.68.2.004

Radchenko A, Dlussky GM (2018c) New species from the extinct ant genus Electromyrmex Wheeler (Hymenoptera, Formicidae). Vestnik zoologii 52(5): 361-366. https://doi. org/10.2478/vzoo-2018-0038

Radchenko A, Dlussky GM (2019) The first record of the ant genus Crematogaster (Hymenoptera, Formicidae) from the late Eocene European amber. Annales Zoologici 69(2): 417-421. https://doi.org/10.3161/00034541ANZ2019.69.2.008

Radchenko A, Dlussky G, Elmes GW (2007) The ants of the genus Myrmica (Hymenoptera, Formicidae) from Baltic and Saxonian Amber (Late Eocene). Journal of Paleontology 81(6): 1491-1501. https://doi.org/10.1666/05-066.1 
Radchenko AG, Dlussky GM, Gröhn C (2019) New extinct species of the ant genus Carebara (Hymenoptera, Formicidae) from the Late Eocene European ambers. Annales Zoologici 69(3): 609-616. https://doi.org/10.3161/00034541ANZ2019.69.3.010

Radchenko A, Dlussky GM, Perfilieva K (2018) A new extinct ant genus (Hymenoptera, Formicidae, Myrmicinae) from the Late Eocene Rovno amber - a putative ancestor of the Leptothorax genus group. Myrmecological News 27: 111-117. https://doi.org/10.25849/ myrmecol.news_027:111

Radchenko AG, Perkovsky EE (2009) Monomorium kugleri n. sp., a new fossil ant species (Hymenoptera, Formicidae, Myrmicinae) from the Late Eocene Rovno Amber (Ukraine). Israel Journal of Entomology 39: 99-103. https://www.antwiki.org/wiki/images/b/bd/ Radchenko_\&_Perkovsky_2009.pdf

Wheeler WM (1915) The ants of the Baltic Amber. Schriften der Physikalisch-ökonomischen Gesellschaft zu Königsberg in Preußen 55(2): 1-142. https://www.antwiki.org/wiki/ images/e/ec/Wheeler_1915i.pdf 